\title{
Three New Species of Hemicyclops (Copepoda, Cyclopoida, Clausidiidae) from Korea
}

\author{
Seong Yong Moon and Il-Hoi Kim* \\ Department of Biology, Kangnung National University, Gangneung 210-702, Korea
}

\begin{abstract}
Three new species of Hemicyclops, H. parilis, H. nasutus and H. membranatus are described from Korean coasts. Hemicyclops parilis n. sp. is closely similar to H. gomsoensis Ho and Kim, but distinguishable from the latter species by having the different shape of genital double somite and spermatophore. Hemicyclops nasutus $\mathrm{n}$. sp. is distinguishable from congeners by having five setae on the first segment of antennule and the ratio 4.26 : 1 of the length to width of caudal ramus. Hemicyclops membranatus $\mathrm{n}$. $\mathrm{sp}$. is characterized by the possession of the membranous fringe along margins of cephalothorax and a claw on the third antennal segment.
\end{abstract}

Keywords: Hemicyclops, sibling species, association, Crustacea, Polychaeta

\section{INTRODUCTION}

Hemicyclops Boeck, 1873 is the largest and primitive genus in the family Clausidiidae. Species of this genus are diverse ecologically, with some of them living free but mostly in association with a great variety of marine invertebrates (Karanovic, 2008). Kim (2009) counted 38 species in Hemicyclops including three species he described as new. Recently, Ohtsuka et al. (2010) recorded Hemicyclops xiamenensis as new from a plankton sample collected at the mouth of the Jiulong River, China.

In Korea, four species of Hemicyclops have been described: H. ctenidis Ho and Kim, 1990 associated with a polychaete (Ho and Kim, 1990), H. gomsoensis Ho and Kim, 1991 and H. saxatilis Ho and Kim, 1991 both found in crustacean burrows (Ho and Kim, 1991), and H. ventriplanus Kim, 2000 associated with a thalassinidean crustacean (Kim, 2000).

During general field surveys done recently for collecting copepods associated with marine invertebrates, one of the authors (S.Y. Moon) found several species of Hemicyclops, of which three species have turned out to be new to science. This paper deals with descriptions of these three new species.

\section{MATERIALS AND METHODS}

Copepod material studied in this work were collected from intertidal and sublittoral soft bottoms in the southern and

\footnotetext{
*To whom correspondence should be addressed

Tel: 82-33-640-2312, Fax: 82-33-642-6124

E-mail: ihkim@gwnu.ac.kr
}

Yellow Sea coasts of Korea. One of three described species was collected from crustacean burrows, and other two were extracted from washings of polychaetes dug out on beaches. Specimens of Hemicyclops gomsoensis Ho and Kim, 1991, which were examined for a comparison with $H$. parilis $\mathrm{n}$. sp., were collected from burrows of the thalassinidean crustacean Upogebia major (De Haan) at Muchangpo (36 $14^{\prime}$ $25^{\prime \prime} \mathrm{N}, 126^{\circ} 31^{\prime} 46^{\prime \prime} \mathrm{E}$ ) on the Yellow Sea coast on May 6, 2000.

Copepod specimens were fixed with and have been preserved in $80 \%$ ethanol. Before dissection and microscopic observation, specimens were immersed in lactic acid for about an hour. Dissections of specimens were done using reverse slide method of Humes and Gooding (1964). All figures were drawn with the aid of a drawing apparatus equipped on the light microscope. Type specimens will be deposited in the National Institute of Biological Resources (NIBR), Incheon, Korea.

\section{SYSTEMATIC ACCOUNTS}

Order Cyclopoida Burmeister, 1834

Family Clausidiidae Embleton, 1901

Genus Hemicyclops Boeck, 1873

Hemicyclops parilis n. sp.

(Figs. 1-3, 4A, B)

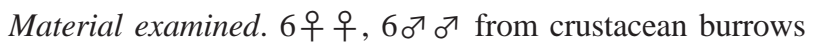
on intertidal mud flat, Namhae Island $\left(34^{\circ} 49^{\prime} 45^{\prime \prime} \mathrm{N}, 128^{\circ} 02^{\prime}\right.$ $14^{\prime \prime}$ E), 21 October 2010, collected by S. Y. Moon. Holotype (우), allotype ( $\sigma^{\top}$ ), and paratypes (4우 우, $4 \sigma^{7}$ ) will be deposited in the National Institute of Biological Resources 


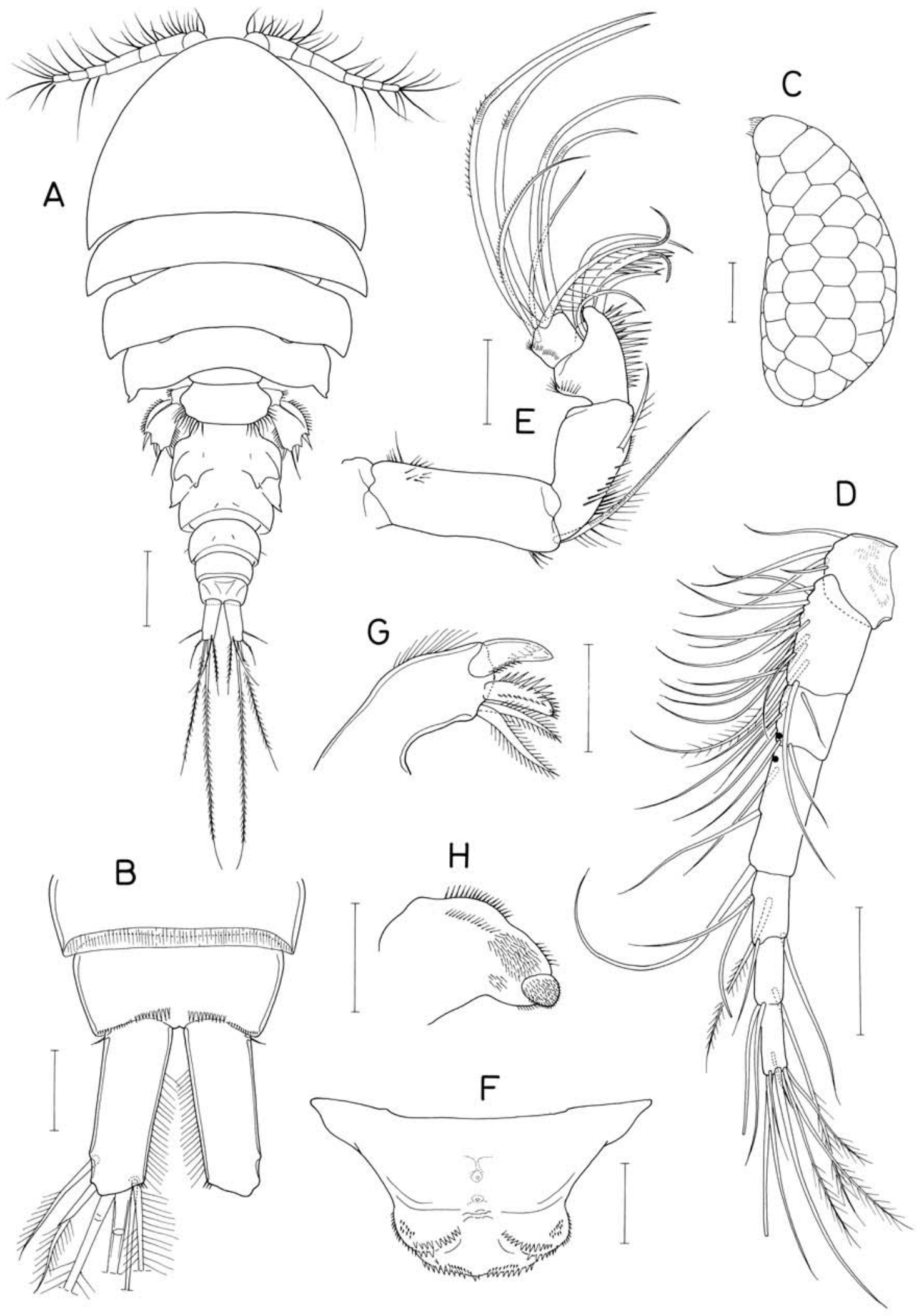

Fig. 1. Hemicyclops parilis n. sp., female. A, habitus, dorsal; $B$, anal somite and caudal rami, ventral; $C$, egg sac; $D$, antennule; $E$, antenna; F, labrum; G, mandible; $H$, paragnath. Scales: A, $0.2 \mathrm{~mm} ; \mathrm{B}, \mathrm{E}-\mathrm{H}, 0.05 \mathrm{~mm} ; \mathrm{C}, \mathrm{D}, 0.1 \mathrm{~mm}$. 
(NIBR), Incheon, Korea. Dissected paratypes (1우, $1 \sigma^{7}$ ) are kept in the collection of the author.

Female. Body (Fig. 1A) $1.64 \mathrm{~mm}$ long, excluding setae of caudal rami. Greatest width $757 \mu \mathrm{m}$ across second pedigerous somite. Prosome $942 \mu \mathrm{m}$ long. Cephalothorax $474 \times$ $751 \mu \mathrm{m}$, with pointed posterolateral corners. Fourth pedigerous somite with notch at posterolateral corners. Urosome (Fig. 4A) 5-segmented. Fifth pedigerous somite $254 \mu \mathrm{m}$ wide, with row of long setules along posterodorsal margin. Genital double somite flat, 250 (measured along mid-dorsal axis) $\times 308 \mu \mathrm{m}$, with paired dorsal and lateral flaps and several setules on dorsal surface (Fig. 4A); dorsal flap branched, bearing minute setules along margin of lateral branch and 1 setule near tip of inner branch; lateral flap flesh and ended with sharp point. Three postgenital somites $98 \times 204,77 \times$ 162 , and $62 \times 137 \mu \mathrm{m}$. Genital double and first 2 postgenital somites fringed with membrane along posteroventral margin. Anal somite with transverse row of spinules along posteroventral border. Caudal rami divergent (Fig. 1B); each ramus $113 \times 42 \mu \mathrm{m}$ (ratio $2.69: 1$ ), with setules along inner margin, 1 proximolateral setule and 7 setae; outer subdistal and distal setae spiniform proximally but setiform distally; dorsal seta naked but other 5 setae pinnate. Egg sac (Fig. 1C) $492 \times 223 \mu \mathrm{m}$, slightly curved inward, and narrowed anteriorly.

Rostrum hemicircular. Antennule (Fig. 1D) 7-segmented and $433 \mu \mathrm{m}$ long, with armature formula 4, 15, 6, 3, 4+ aesthetasc, 2+aesthetasc, and 7+aesthetasc; first segment with minute spinules on ventral surface. One of setae on second, fifth and sixth segments pinnate. Antenna (Fig. 1E) 4segmented, with armatrue formula 1, 1, 4, and 7. First segment with setules on outer and inner margins. Second segment with setules and minute spinules on outer margin. Third segment with large and smaller spiunules on outer margin and row of minute setules on inner margin; outer distal corner projected. Fourth segment $256 \times 282 \mu \mathrm{m}$, slightly wider than long, with 2 rows of minute setules near inner margin.

Labrum (Fig. 1F) with transverse row of denticles on dorsal surface and along posterior margin. Mandible (Fig. 1G) with setules on distal half of posterior margin and 4 distal elements consisting of 1 stout claw-like element, 1 spiniferous plate and 2 pinnate setae. Paragnath (Fig. 1H) bi-articulated, with larger proximal article bearing spinules and minute setules and small distal article bearing minute spinules. Maxillule (Fig. 2A) ramified distally, with 5 setae on broader ramus and 3 setae on narrower ramus. Maxilla (Fig. 2B) 2-segmented. Proximal segment with row of small setules proximally and 2 large setae distally, one of these 2 setae accompanied by 1 setule proximally; distal segment with 2 setae and 2 spines; one of spines ramified, each ramus bearing 1 and 2 barbs. Maxilliped (Fig. 2C) 4-segmented. First segment with 2 large inner setae. Second segment with 2 large inner setae and longitudinal row of minute setules along inner side. Third segment small and unarmed. Fourth segment armed with 2 spiniferous spiniform elements and 3 naked setae; shorter one of spiniform elements accompanied by proximal accessory seta.

Legs 1-4 (Fig. 2D-F, Fig. 3A) with 3-segmented rami, with exopods distinctly longer than endopods. Armature formula of these legs as follows:

Leg 1: coxa 0-1; basis 1-I; exopod I-0; I-1; I,3,4; endopod $0-1 ; 0-1 ; \mathrm{I}, 2,3$

Leg 2: coxa 0-1; basis 1-0; exopod I-0; I-1; II,2,5; endopod $0-1 ; 0-2 ; \mathrm{I}, \mathrm{II}, 3$

Leg 3: coxa 0-1; basis 1-0; exopod I-0; I-1; II,II,5; endopod $0-1 ; 0-2 ;$ I,II,3

Leg 4: coxa 0-1; basis 1-0; exopod I-0; I-1; I,II,5; endopod $0-1 ; 0-2 ;$ I,II, 2

Inner spine on basis of first leg $67 \mu \mathrm{m}$ long. Outer seta on basis of leg 1 distinctly larger than those of legs 2-4. Three outer spines on leg 1 exopod tipped by setule-like element. Intercoxal plate of leg 1 with setules along posterior margin but those of legs 2-4 replaced by spinules. Two inner setae on terminal segment of leg 4 endopod spiniform, proximally pinnate but spiniferous distally.

Leg 5 2-segmented. Proximal segment articulated from fifth pedigerous somite, with 1 pinnate dorsodistal seta. Distal segment (Fig. 3B) $160 \times 81 \mu \mathrm{m}(1.98: 1$ ), with spinules on both outer and inner margin, and 3 spines and 1 seta on distal margin. Leg 6 not seen.

Male. Body (Fig. 3C) resembling in form that of female and $1.56 \mathrm{~mm}$ long. Maximum width $640 \mu \mathrm{m}$ across second pedigerous somite. Prosome $862 \mu \mathrm{m}$ long. Cephalothorax $492 \times$ $634 \mu \mathrm{m}$. Urosome (Fig. 3D) 6-segmented. Fifth pedigerous somite $265 \mu \mathrm{m}$ wide. Genital somite nearly circular, $252 \times$ $274 \mu \mathrm{m}$, slightly wider than long. Four abdominal somites $100 \times 150,95 \times 129,43 \times 118$, and $65 \times 111 \mu \mathrm{m}$, respectively. Caudal ramus $100 \times 43 \mu \mathrm{m}(2.33: 1)$, slightly shorter than that of female. Spermatophore (Fig. 4B) L-shaped, 288 $\mu \mathrm{m}$ long along middle axis, with projection proximally near opening.

Rostrum as in female. Antennule with 1 additional seta on third and fourth segments, at places of dots in Fig. 1D. Antenna as in female.

Labrum, mandible, paragnath, and maxillule similar to those of female. Maxilla (Fig. 3E) with one of spines on distal segment transformed to stout claw. Maxilliped (Fig. 3F) composed of 3 segments and terminal claw. First segment with 1 large seta. Second segment greatly expanded proximally and gradually narrowed distally, with 2 setae near middle of inner side, and 1 row of minute spinules and 2 


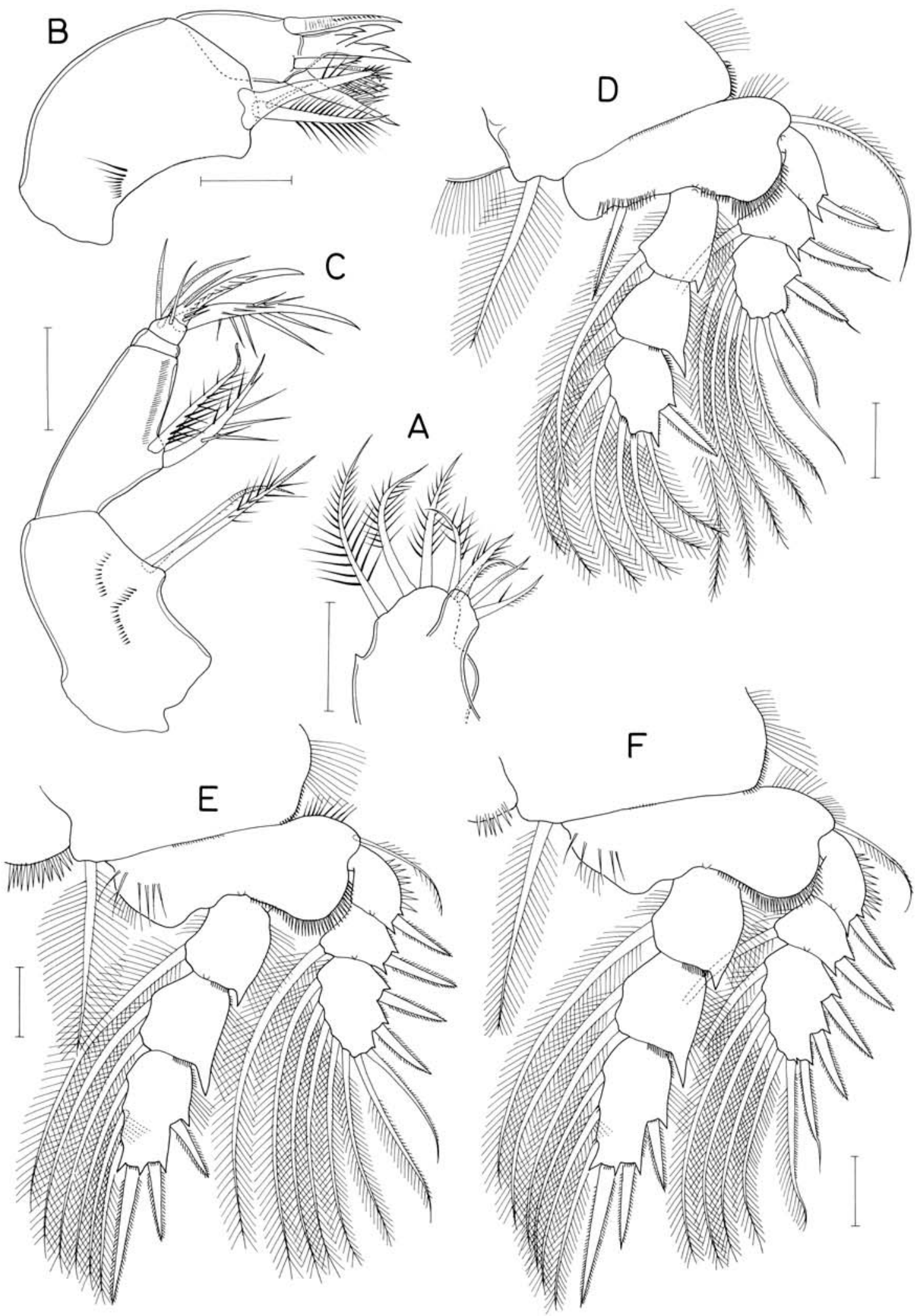

Fig. 2. Hemicyclops parilis n. sp., female. A, maxillule; B, maxilla; C, maxilliped; D, leg 1; E, leg 2; F, leg 3 . Scales: 0.05 mm for all. 
Three New Species of Hemicyclops

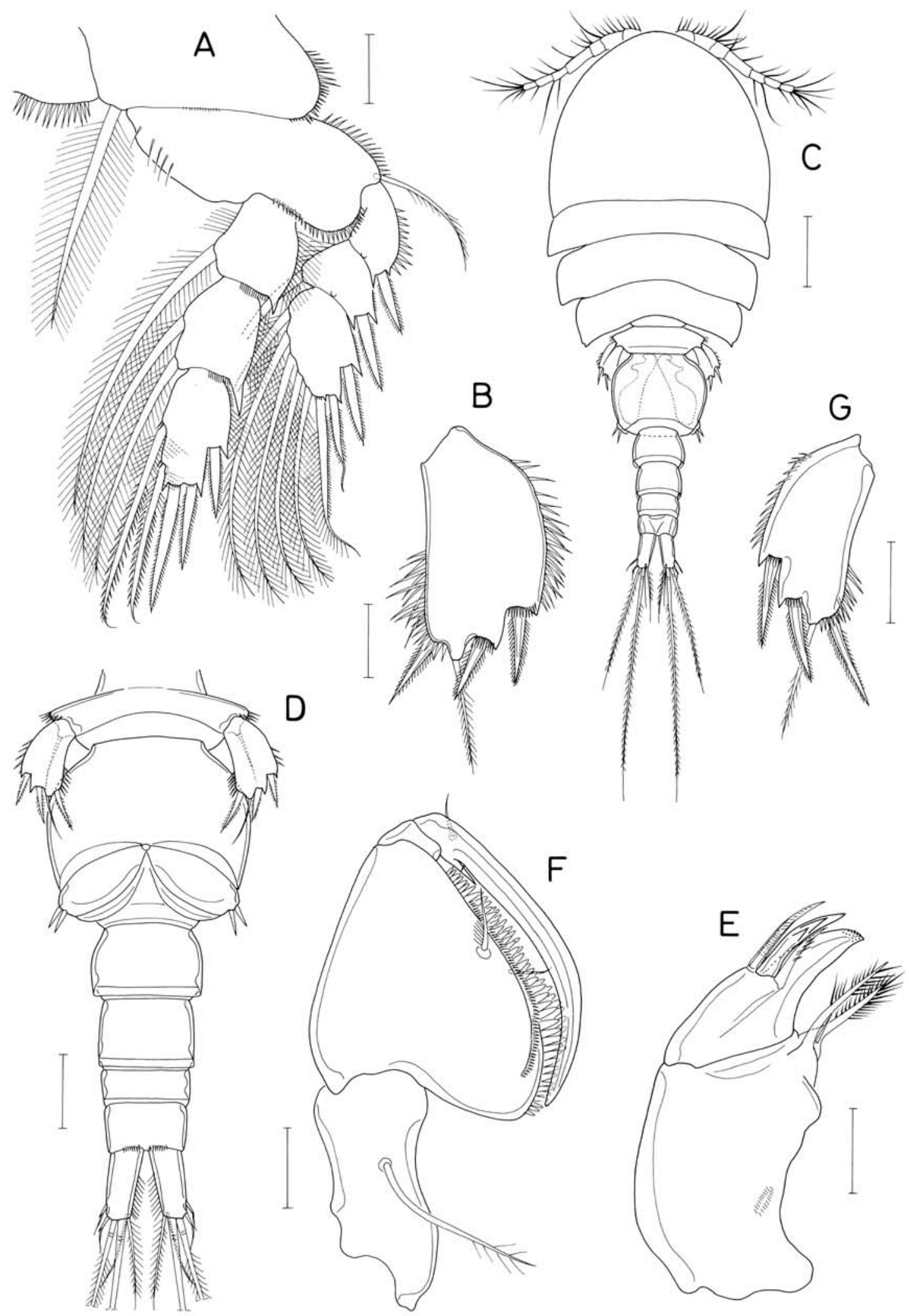

Fig. 3. Hemicyclops parilis n. sp. Female: A, leg 4; B, distal segment of leg 5. Male: C, habitus, dorsal; D, urosome, ventral; $E$, maxilla; F, maxilliped; G, distal segment of leg 5. Scales: A, B, E-G, $0.05 \mathrm{~mm} ; \mathrm{C}, 0.2 \mathrm{~mm} ; \mathrm{D}, 0.1 \mathrm{~mm}$. 


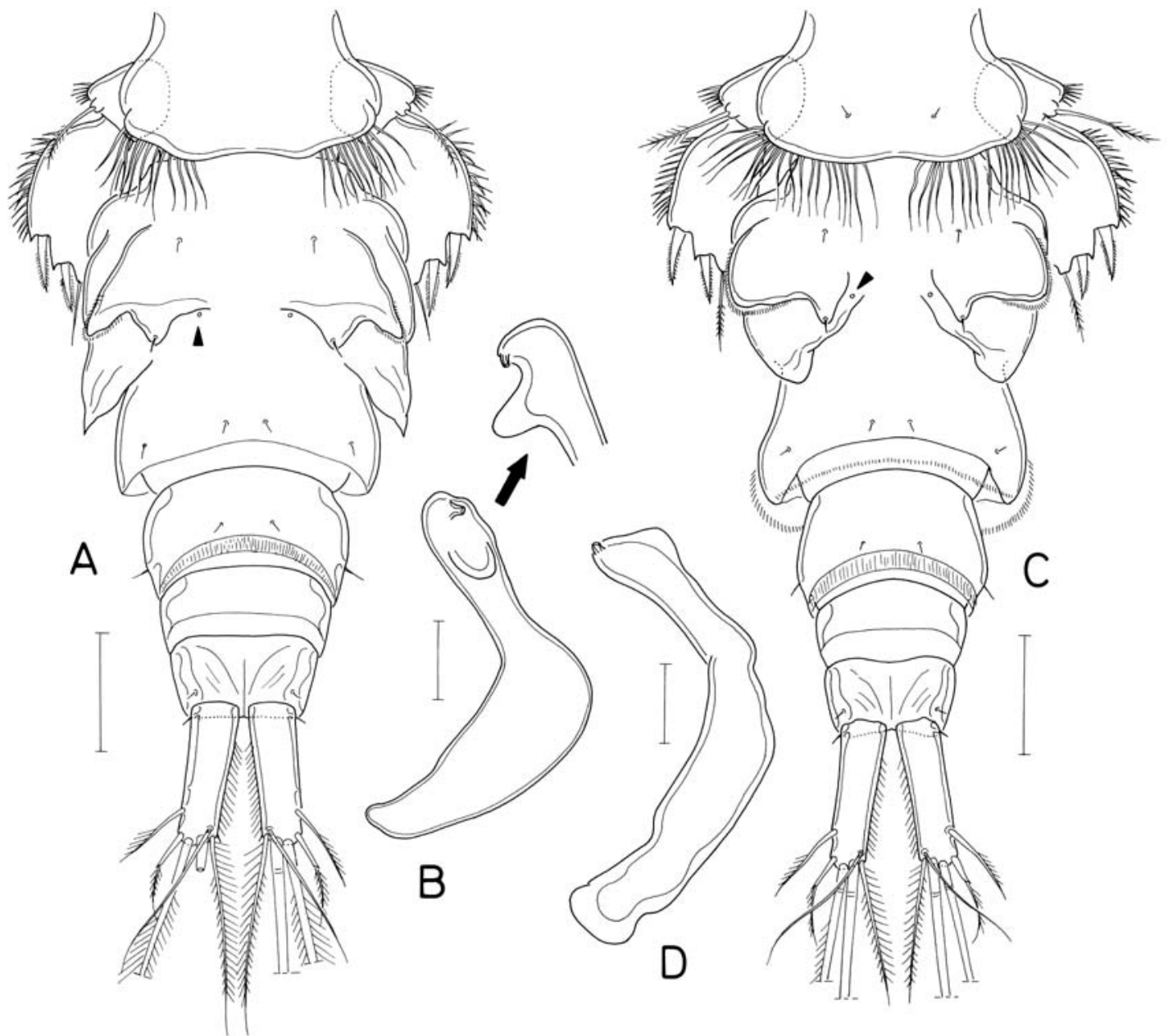

Fig. 4. Hemicyclops parilis $\mathrm{n}$. sp.: A, female urosome, dorsal; $\mathrm{B}$, spermatophore from male. Hemicyclops gomsoensis Ho and Kim: C, urosome, dorsal; D, spermatophore from male. Arrowheads indicate copulatory pore. Scales: A, C, $0.1 \mathrm{~mm} ; \mathrm{B}, \mathrm{D}, 0.05 \mathrm{~mm}$.

rows of larger spinules along inner margin. Third segment small and unarmed. Terminal claw nearly as long as 2 distal segments, proximally with 1 seta, 1 spiniform process, and 1 minute setule.

Leg 1 lacking inner distal spine on basis, otherwise similar to that of female. Legs 2-4 as in female. Leg 5 with proximal segment completely fused to fifth pedigerous somite, leaving only 1 dorsal seta. Distal segment (Fig. 3G) $120 \times$ $57 \mu \mathrm{m}(2.11: 1)$, narrower than distal segment female leg 5. Leg 6 represented by 2 spines genital flap (Fig. 3D).

Etymology. The specific name parilis is a Latin meaning "similar" and alludes to the close similarity between the new species and $H$. gomsoensis.

Remarks. Hemicyclops parilis n. sp. is most closely related to Hemicyclops gomsoensis Ho and Kim, 1991. The latter species was originally discovered from the burrows of the crab Macrophthalmus japonicus De Haan in the Yellow Sea, but later, its major host has turned out to be Upogebia major (De Haan). Because, at first, the specimens of the new species were suspected to be $H$. gomsoensis, we carefully compared it with newly obtained specimens of $H$. gomsoensis. The comparison revealed that almost all of morphological features of these two species are fundamentally identical. Their body forms, the setation of legs, morphologies of other appendages, and even the form of egg sac revealed no difference between the two species. Nevertheless, two significant points allow to determine that they are different species: the shapes of the female genital double-somite and spermatophore.

The two species have in common two pairs of flaps (anterior and posterior) on the genital double-somite in the female (Fig. 4A, C). The anterior flap is a device holding the girdle of spermatophore, positioning just lateral to the copulatory pore. In both species the anterior flap is weakly bilobed, with the outer and inner lobes. This anterior flap is not so different between the two species. The posterior flap 
is, however, markedly differs between the two; in H. gomsoensis it is positioned dorsolaterally, with blunt posterior apex (Fig. 4C), whereas, that of $H$. parilis is positioned laterally, with a pointed posterior apex (Fig. 4A).

The shapes of the spermatophores of the two species are invariable within a species and clearly different between the two species. The spermatophore of $H$. gomsoensis is C-shaped (Fig. 4D) and, thus, contrasted to that of the new species which is L-shaped, with a prominent process near the opening (Fig. 4B). We consider that the difference in the shape of the spermatophore is a decisive evidence to recognize that $H$. parilis is not conspecific with $H$. gomsoensis. They may be recognized as sibling species.

Ho and Kim (1991) recorded the ratio of the length to width of caudal ramus in the female of H. gomsoensis as 2.7 : 1. But in newly examined female specimens those were sympatric with $H$. parilis it was measured as $3.11-3.43: 1$, whereas that of $H$. parilis was measured as $2.44-2.93: 1$. Therefore, the difference in the figure of the caudal ramus would be useful in the distinction of these species.

The genus Hemicyclops is becoming a speciose genus and the morphological differences among species in this genus are becoming very slight. Consequently, some delicate morphological characters appear to be taxonomically important. These characters probably include the shape of the female genital double-somite and spermatophore and the setation and ornamentation on the terminal segment of female maxilliped.

\section{Hemicyclops nasutus n. sp.} (Figs. 5, 6)

Material examined. One 우 (holotype) from an unidentified polychaete at the Manripo Beach $\left(36^{\circ} 47^{\prime} 08^{\prime \prime} \mathrm{N}, 126^{\circ} 08^{\prime}\right.$ $24^{\prime \prime} \mathrm{E}$ ), low intertidal, 12 August 2010, collected by S.Y. Moon. Holotype (dissected and mounted on a slide) will be deposited in the National Institute of Biological Resources (NIBR), Incheon, Korea.

Female. Body (Fig. 5A) moderately narrow and $1.63 \mathrm{~mm}$ long. Maximum width $611 \mu \mathrm{m}$ measured across cephalothorax. Prosome $850 \mu \mathrm{m}$ long, and cephalothorax $483 \mu \mathrm{m}$ long. Cephalothorax and 2 following somites fringed with membrane along posterodorsal margin. Urosome (Fig. 5B) 5segmented. Fifth pedigerous somite $233 \mu \mathrm{m}$ wide, with small transparent posterolateral process on both sides. Genital double somite $256 \mu \mathrm{m}$ long, with prominent anterolateral expansions ( $244 \mu \mathrm{m}$ wide across this area), narrow posterior half $(147 \mu \mathrm{m}$ wide across this area), and dorsal stepwise curvature seen evidently in lateral view (Fig. 5C). Three postgenital somites $111 \times 136,83 \times 133$, and $75 \times 118 \mu \mathrm{m}$, respectively. Anal somite with minute spines along dorso- distal margin and several larger spinules along ventrodistal margin (Fig. 5D). Caudal ramus $183 \times 43 \mu \mathrm{m}$ (ratio $4.26: 1$ ) narrowest in middle and broader in extremities, with setules on distal part of inner margin, 1 small outer proximal setules, and 6 setae. Outer subdistal and distal setae spiniform and tipped by naked setule. Dorsal seta naked. Other 3 distal setae pinnate.

Rostrum hemicircular. Antennule (Fig. 5E) $383 \mu \mathrm{m}$ long and 7-segmented, with armature formula 5, 15, 6, 4, 4+ aesthetasc, $2+$ aesthetasc, and $7+$ aesthetasc. One of setae pinnate on first, fifth, sixth, and seventh segments. Aesthetascs on 3 distal segments recurved. Antenna (Fig. 4F) 4 segmented with armature formula 1, 1, 4, and 7. First segment with several setules on outer margin. Second segment with long setules proximally and spinules distally on outer margin. Third segment with spinules of various sizes on outer margin and row of small spinules on inner margin. Fourth segment $42 \times 33 \mu \mathrm{m}, 1.27$ times as long as wide.

Labrum (Fig. 5G) with spinules of various sizes posteriorly. Mandible (Fig. 4H) with smooth margins and 4 distal elements: claw-like element, spiniferous plate, and 2 pinnate setae. Paragnath lobate, with spinules and setules. Maxillule (Fig. 6A) distally ramified, with 5 setae on broader ramus and 3 setae on narrower ramus. Maxilla (Fig. 6B) 2-segmented. Proximal segment with row of small setules proximally and 2 large setae distally, one of these 2 setae accompanied by 1 setule proximally; distal segment with 2 setae, 1 spine and 1 spiniform branched process; one of branches bearing 1 barb. Maxilliped (Fig. 6C) 4-segmented. First segment with 2 large inner setae. Second segment with 2 inner setae of unequal sizes and longitudinal row of large setules along distal part of inner side. Third segment small and unarmed. Fourth segment armed with 2 spiniform elements and 3 naked setae.

Legs 1-4 with 3-segmented rami, with exopods distinctly longer than endopods. Armature of these legs as follows:

Leg 1: coxa 0-1; basis 1-I; exopod I-0; I-1; II,2,4; endopod $0-1 ; 0-1 ; \mathrm{I}, 2,3$

Legs 2 \& 3: coxa 0-1; basis 1-0; exopod I-0; I-1; II,II,5; endopod $0-1 ; 0-2 ;$ I,II,3

Leg 4: coxa 0-1; basis 1-0; exopod I-0; I-1; I,II,5; endopod $0-1 ; 0-2 ;$ I,II, 2

Basis of leg 1 with pointed process on inner side of posterior margin near inner spine; inner spine $42 \mu \mathrm{m}$ long. Four outer spines on leg 1 exopod and distal spine on exopod of legs 2-4 tipped by setule-like element. Intercoxal plate of leg 1 with setules along posterior margin but those of legs 2-4 replaced by spinules. Two inner setae on terminal segment of leg 4 endopod spiniform, proximally pinnate but spiniferous distally.

Leg 5 2-segmented. Proximal segment articulated from 


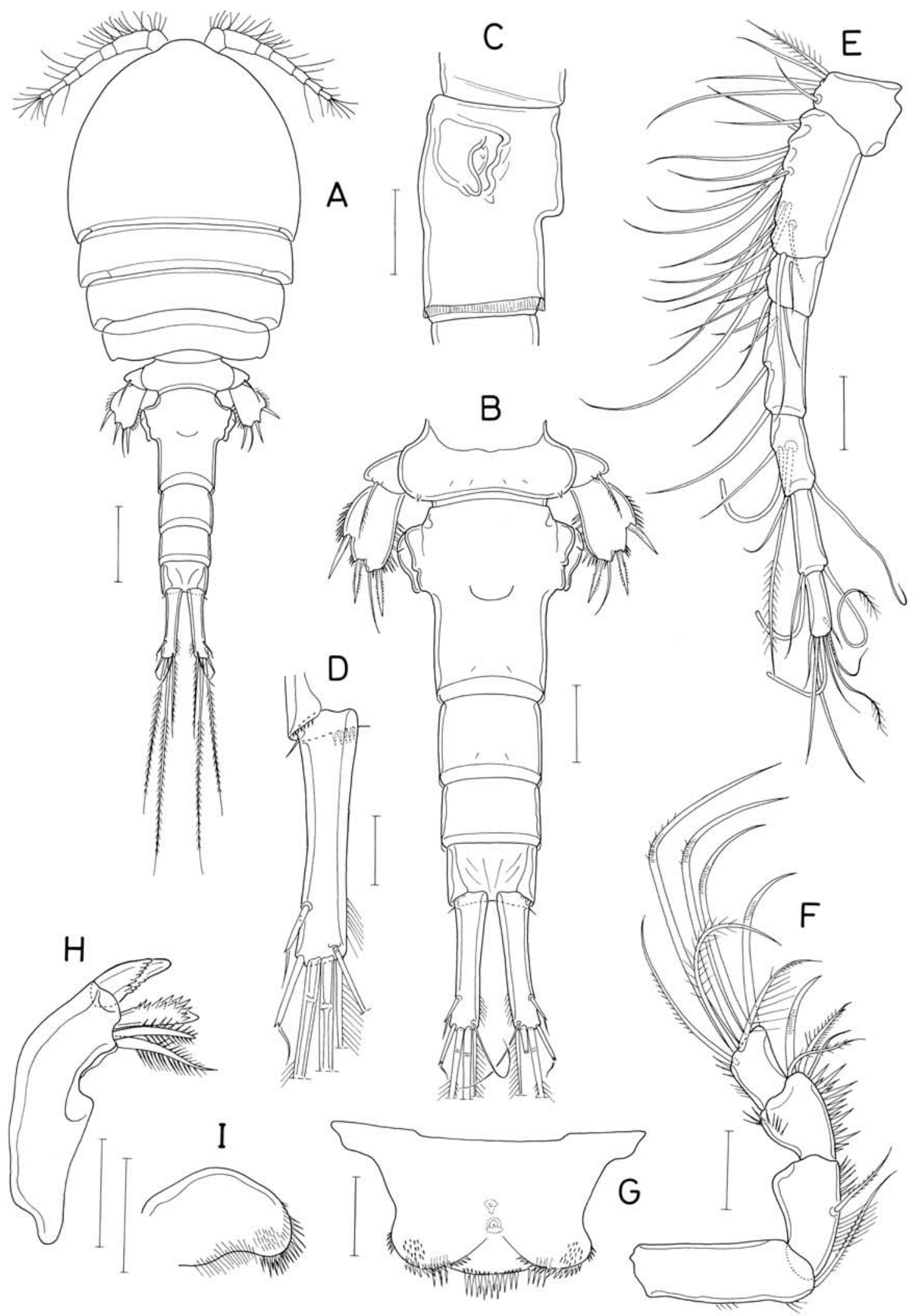

Fig. 5. Hemicyclops nastus $n$. sp., female. $A$, habitus, dorsal; $B$, urosome, dorsal; $C$, genital double somite, left; $D$, left caudal ramus, dorsal; E, antennule; F, antenna; G, labrum; H, mandible; I, paragnath. Scales: A, $0.2 \mathrm{~mm}$; B, C, $0.1 \mathrm{~mm}$; D-I, $0.05 \mathrm{~mm}$. 
Three New Species of Hemicyclops
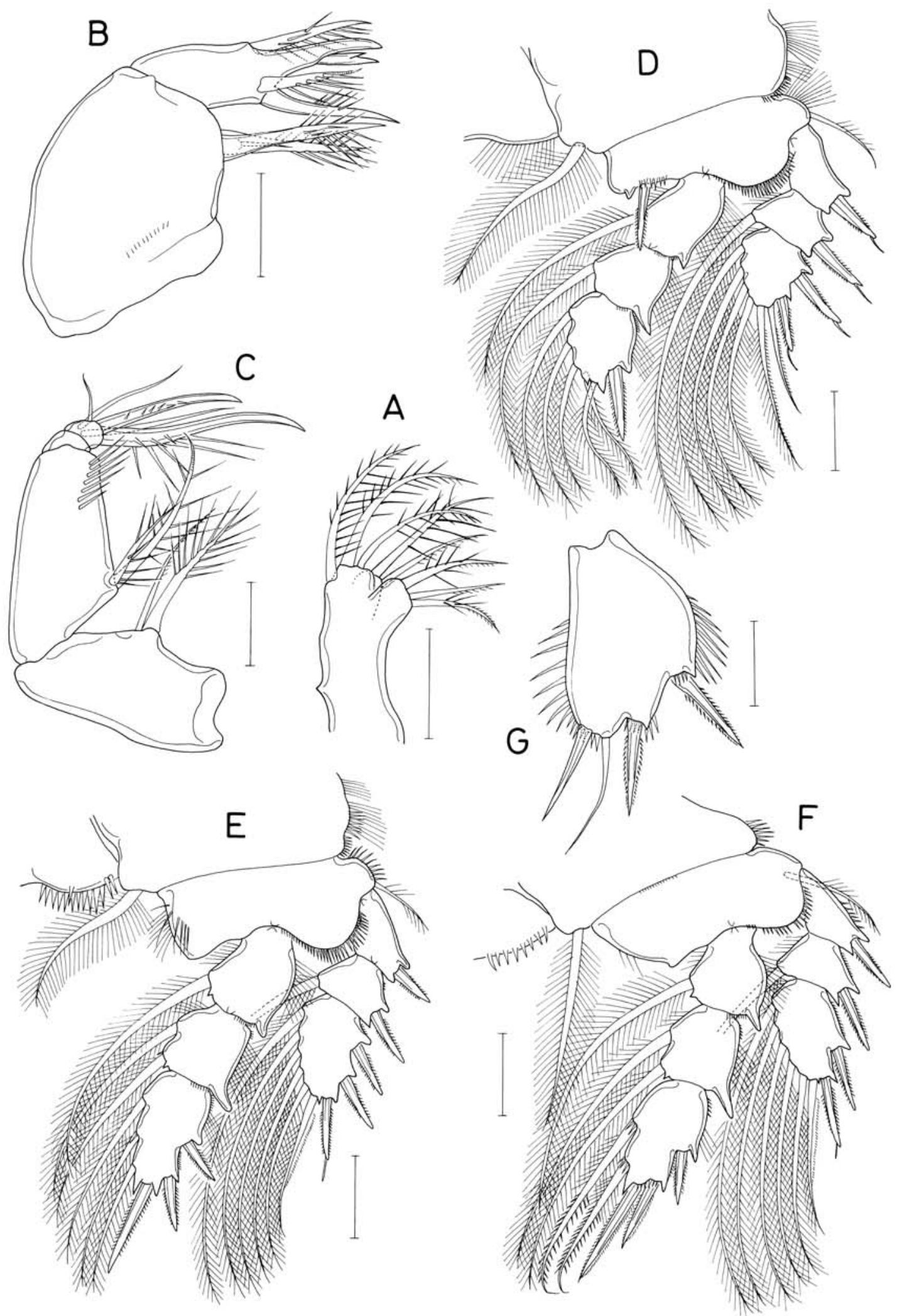

Fig. 6. Hemicyclops nastus n. sp., female. A, maxillule; B, maxilla; C, maxilliped; D, leg 1; E, leg 2; F, leg 4; G, distal segment of leg 5. Scales: $0.05 \mathrm{~mm}$ for all. 
fifth pedigerous somite, with 1 pinnate dorsodistal seta. Distal segment (Fig. 6G) $120 \times 77 \mu \mathrm{m}(1.56: 1)$, with spinules on both outer and inner margin, and 3 spines and 1 seta on distal margin. Leg 6 not seen.

Male. Unknown.

Etymology. The specific name nasutus is a Latin, meaning "having long nose". It alludes to the nose-like dorsal hump on the genital double-somite in the female of the new species. Remarks. One of significant features of Hemicyclops nasutus n. sp. may be the possession of five (rather than four) setae on the first segment of antennule. The following seven species in the genus are known to have five setae on that segment: H. cylindraceus (Pelseneer, 1929); H. livingstoni (T. Scott, 1894); H. perinsignis Humes, 1973; H. spinulosus Itoh and Nishida, 1998; H. minutus Mulyadi, 2005; H. nichollsi Karanovic, 2008; and H. sebastiani Kihara and Rocha, 1993.

Having the ratio of the length to width of the caudal ramus, $4.26: 1$, the new species comparable only with $H$. cylindraceus, because $H$. sebastiani reveals the ratio 12.5 : 1 (Kihara and Rocha, 1993) and the remaining five species exhibit the ratio less than $3.0: 1$. According to Stock (1954), H. cyclindraceus (as Tococheres cylindraceus) has a narrow, cylindrical body, two claws and two setae on the third segment of antenna, a claw-like enlarged spine on the terminal segment of female maxilliped, and four setae on the distal segment of leg 5. These features are not observable in the new species.

Although five species in Hemicyclops, i.e., H. aberdonensis (T. and A. Scott, 1903), H. australis Nicholls, 1994, H. bacescui Serban, 1956, H. leggii (Thompson and Scott, 1903), and H. tamilensis (Thompson and Scott, 1903), are uncertain for their setation on the first segment of the antennule, these species are readily distinguishable from $H$. nasutus, because they also have the caudal ramus not exceeding the ratio 3.0:1 and the following features not applicable to $H$. nasutus: the presence of nine elements on the third exopodal segment and seven elements on the third endopodal segment of leg 4 in H. aberdonensis (see T. and A. Scott, 1892); the rounded lateral margins of the anterior expansion of the genital double-somite and the produced inner distal corner of the third antennal segment in H. Australis (see Nicholls, 1944); a subdivided female genital double-somite without a prominent lateral expansion and the projected outer distal corner of the third antennal segment in $H$. bacescui (see Stock, 1959); the only five elements (one spine and four setae) on the third endopodal segment of leg 1 in $H$. legii (see Thompson and Scott, 1903); and a 6-segmented female urosome and the narrow distal segment of leg 5 (see Fig. 25 in Pl. 17 of Thompson and Scott, 1903) in H. tamilensis.

\section{Hemicyclops membranatus n. sp.} (Figs. 7-9)

Material examined. 4 우 우, $10^{7}$ from washing of an unidentified polychaete from intertidal sands at Sinjin Island, Taean $\left(36^{\circ} 41^{\prime} 00^{\prime \prime} \mathrm{N}, 126^{\circ} 08^{\prime} 18^{\prime \prime} \mathrm{E}\right), 9$ October 2010, collected by S.Y. Moon. Holotype (우) and paratypes ( 2 우 우) will be deposited in the National Institute of Biological Resources (NIBR), Incheon.

Female. Body (Fig. 7A) with flat prosome and cylindrical urosome. Body length $1.83 \mathrm{~mm}(1.90-1.69 \mathrm{~mm})$, based on 4 specimens. Dissected specimen $1.88 \mathrm{~mm}$ long. Prosome $1.09 \mathrm{~mm}$ long, with maximum width $812 \mu \mathrm{m}$. Prosomal somites becoming distinctly narrowed from anterior to posterior, with rounded anterior and posterior corners. Cephalothorax $560 \mu \mathrm{m}$ long, much wider than long, with membranous fringe along anterior and anterolateral margins. Urosome (Fig. 7B) 5-segmented. Fifth pedigerous somite $273 \mu \mathrm{m}$ wide. Genital double-somite $269 \times 307 \mu \mathrm{m}$, with distinct anterior expansion and narrower posterior half $(179 \mu \mathrm{m}$ across this area); genital area located apically on anterior expansion. Three abdominal somites $127 \times 157,96 \times 142$, and 77 $\times 131 \mu \mathrm{m}$, respectively. Anal somite with transverse row of small spinules along posteroventral margin (Fig. 7C). Caudal rami slightly divergent and widely separated from each other; each ramus $109 \times 45 \mu \mathrm{m}$ (ratio $2.42: 1$ ), gradually narrowed posteriorly, with small denticles on posteroventral margin and 7 setae including small outer proximal seta. Inner distal seta pinnate along inner margin. Inner dorsal seta weakly pinnate. Other 4 setae naked.

Rostrum hardly discernible, with faint posterior margin (Fig. 8A). Antennule (Fig. 7D) $425 \mu \mathrm{m}$ long and 7-segmented, with armature formula 5, 15, 7, 4, 4+aesthetasc, 2+aesthetasc, and 7+aesthetasc. First 2 segments distinctly wider than remaining 5. Aesthetascs on fifth to seventh segments very thin. Antenna (Fig. 7E) 4-segmented. First segment with 1 large seta. Second segment with smaller seta not reaching distal border of segment. Third segment with spinules along inner margin and 4 elements consisting of 1 small subdistal seta, 1 spiniform seta tipped by setule, 1 strong claw, and 1 ordinary seta. Terminal segment $41 \times 18 \mu \mathrm{m}$, with setules on outer margin and 7 setae, inner 4 of latters claw-like.

Labrum (Fig. 8B) with spinules along posterior margin. Mandible (Fig. 8C) with tubercle on ventral side, membranous fringe on dorsal margin, and 4 distal elements consisting of 2 spinulated spines and 2 pinnate setae. Paragnath (Fig. 8D) elongated, with numerous setules. Maxillule (Fig. $8 \mathrm{E}$ ) distally bilobed and armed with 5 setae on broader lobe and 3 setae on narrower lobe, middle one of latters distinctly larger than others. Maxilla (Fig. 8F) 2-segmented. Proximal segment large, distally with 2 large and 1 small setae. 
Three New Species of Hemicyclops

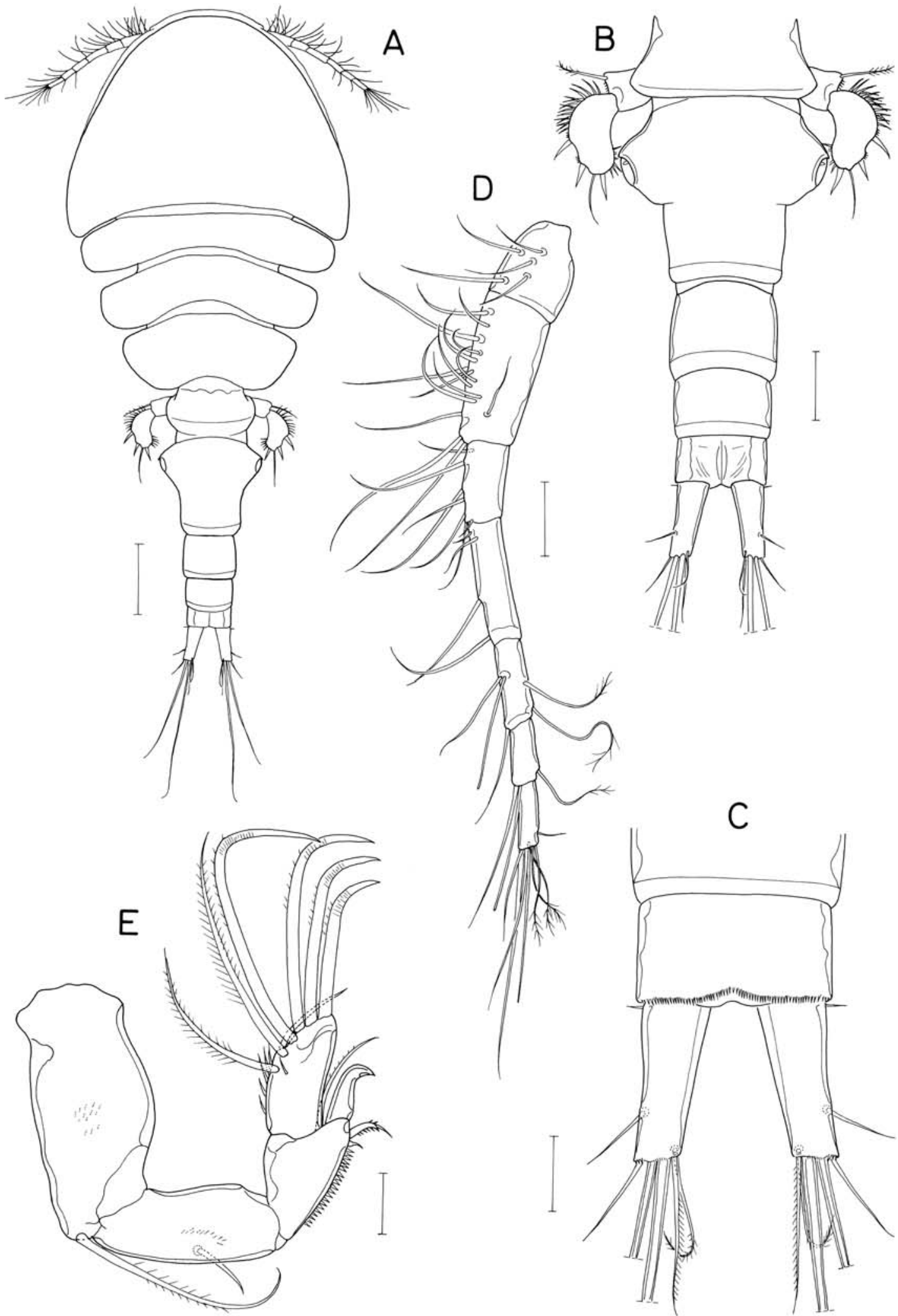

Fig. 7. Hemicyclops membranatus n. sp., female. A, habitus, dorsal; $B$, urosome, dorsal; $C$, posterior part of urosome, ventral; $D$, antennule; E, antenna. Scales: A, $0.2 \mathrm{~mm} ; B, 0.1 \mathrm{~mm}$; C, D, $0.05 \mathrm{~mm} ; \mathrm{E}, 0.02 \mathrm{~mm}$. 


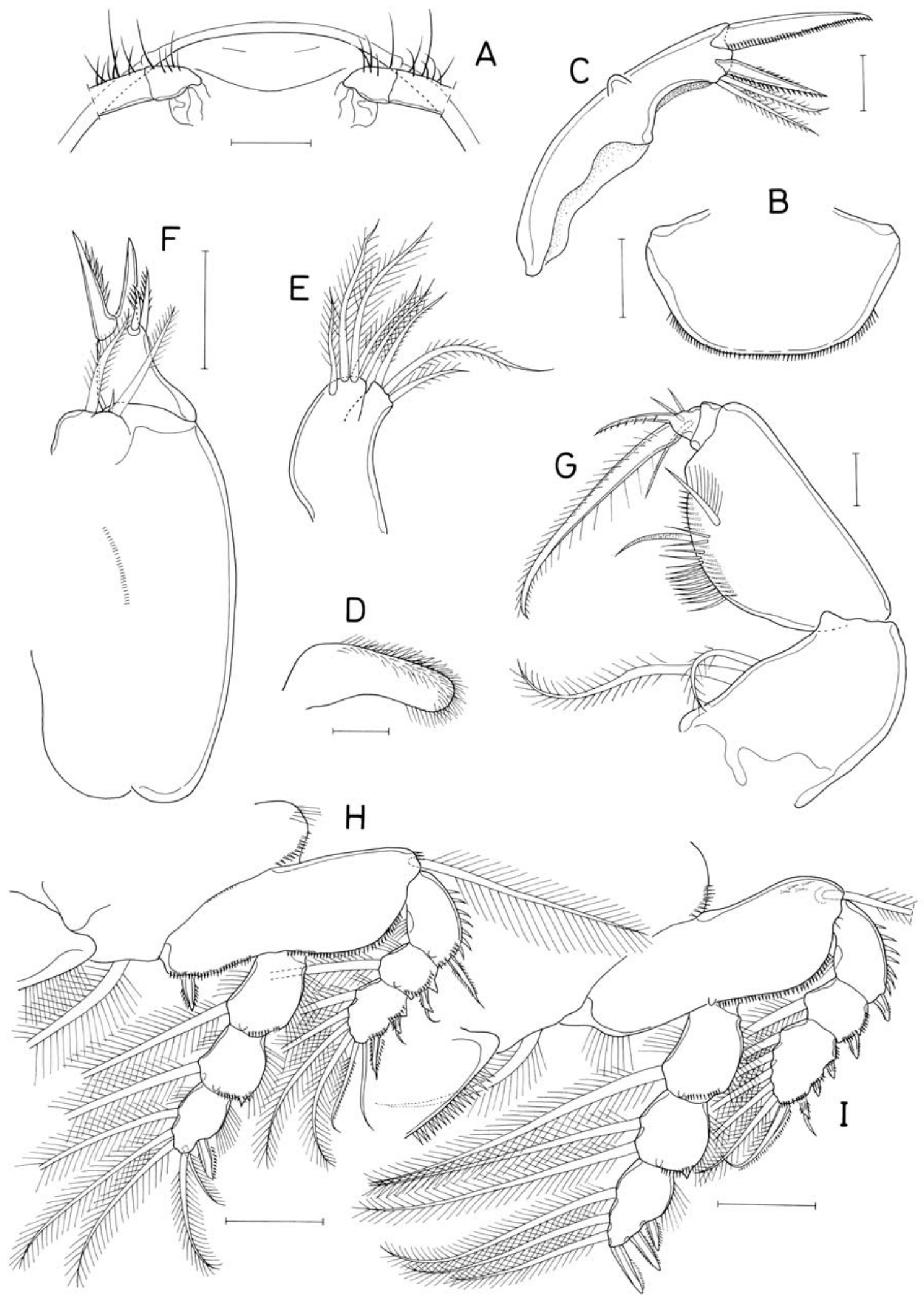

Fig. 8. Hemicyclops membranatus $n$. sp., female. A, rostral area, ventral; $B$, labrum; $C$, mandible; $D$, paragnath; $E$, maxillule; $F$, maxilla; G, maxilliped; H, leg 1; I, leg 2. Scales: A, $0.1 \mathrm{~mm} ; B, F, H, I, 0.05 \mathrm{~mm} ; C-E, G, 0.02 \mathrm{~mm}$. 
Three New Species of Hemicyclops

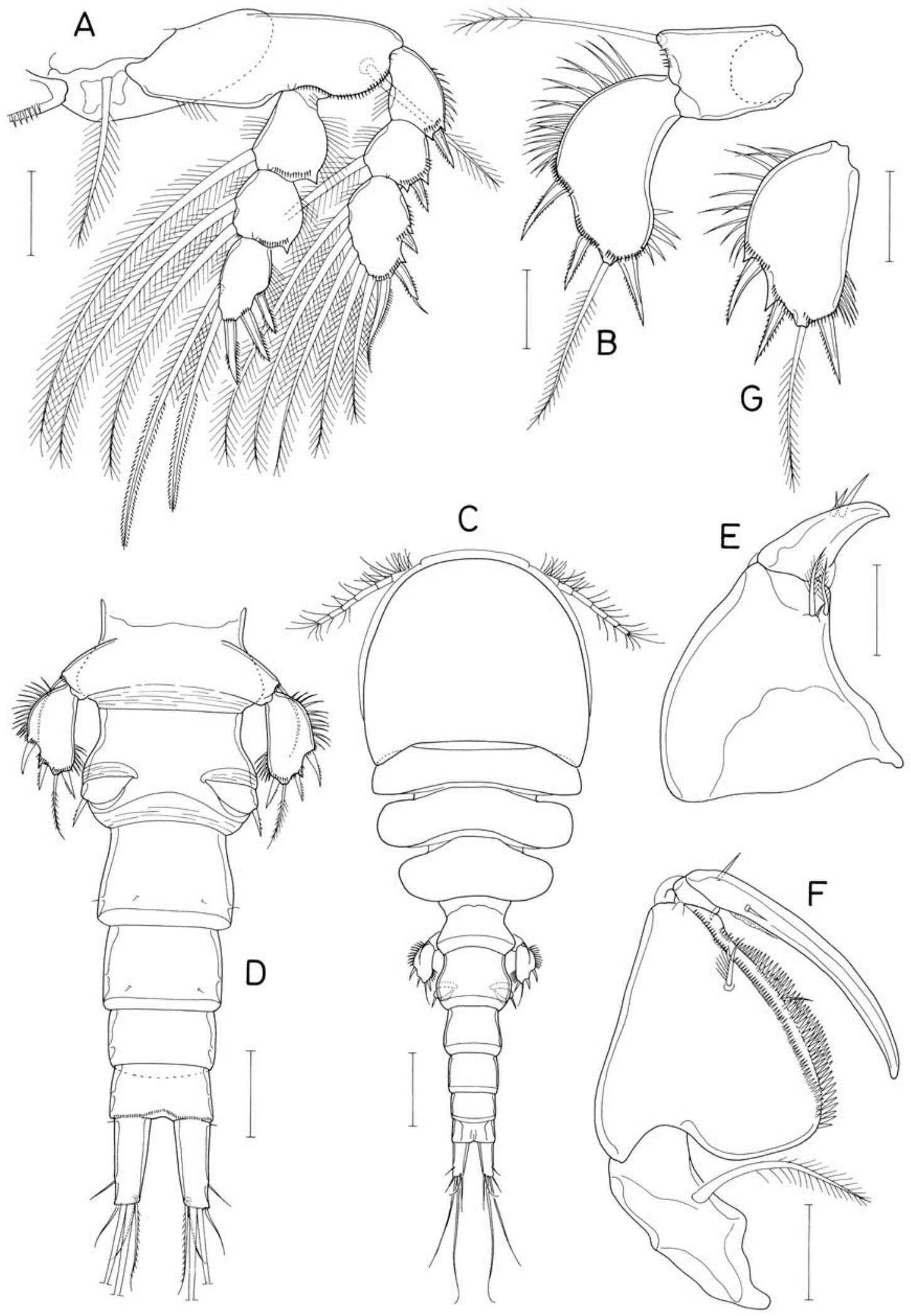

Fig. 9. Hemicyclops membranatus n. sp. Female: A, leg 4; B, leg 5. Male: C, habitus, dorsal; D, urosome, ventral; E, maxilla; $F$, maxilliped; G, free segment of leg 5. Scales: A, B, E-G, $0.05 \mathrm{~mm} ; C, 0.2 \mathrm{~mm} ; D, 0.1 \mathrm{~mm}$. 
Distal segment armed with 1 spiniform process, 1 spiniferous spine, and 2 spiniferous setae. Maxilliped (Fig. 8G) 4segmented. First segment with 2 unequal, pinnate setae. Second segment with convex inner margin, 2 inner setae (1 naked seta and 1 smaller, unilaterally pinnate seta) and 2 longitudinal rows of long setules on inner side. Third segment small and unarmed. Terminal segment armed with 5 elements consisting of 3 naked setae, 1 small spine and 1 enlarged, pinnate spine.

Legs 1-4 with 3-segmented rami. Posterior margin of intercoxal sclerite with setules in leg 1 (Fig. $8 \mathrm{H}$ ), but with spinules in legs 2-4 (Figs. 8I, 9A). Some of outer spines on exopod tipped by setule (Fig. 8H, I, Fig. 9A). Outer seta on basis of legs 1-4 pinnate and large. Inner spine on basis of leg 1 thick but short. Outer spine on first exopodal segment of leg 1 setiform. Two inner setae on third endopodal segment of leg 4 pinnate proximally but spinulated distally (Fig. 9A). Legs 2 and 3 identical in armature and ornamentation. Armature formula of legs 1-4 as follows:

Leg 1: coxa 0-1; basis 1-I; exopod I-0; I-1; II,2,4; endopod $0-1 ; 0-1 ; \mathrm{I}, 2,3$

Legs 2 \& 3: coxa 0-1; basis 1-0; exopod I-0; I-1; III,I,5; endopod $0-1 ; 0-2 ;$ II,I,3

Leg 4: coxa 0-1; basis 1-0; exopod I-0; I-1; II,I,5; endopod $0-1 ; 0-2 ;$ II,I,2

Leg 5 (Fig. 9B) 2-segmented. Proximal segment longer than wide and armed with 1 distal. Distal segment slightly curved, $125 \times 61 \mu \mathrm{m}$ (ratio $2.05: 1$ ), armed with 3 spines and 1 pinnate seta, and ornamented with large setules on proximal half of outer margin and distal part of inner margin and spinules near base of spines. Leg 6 not seen.

Male. Body (Fig. 9C) $1.73 \mu \mathrm{m}$ long. Maximum width $632 \mu \mathrm{m}$. Prosome spatulate and $959 \mu \mathrm{m}$ long. Cephalothorax fringed with membrane along anterior and anterolateral margins, as in female. Urosome (Fig. 9D) 6-segmented. Genital somite $128 \times 203 \mu \mathrm{m}$, narrower than fifth pedigerous somite. Four abdominal somites $124 \times 156,99 \times 136,62 \times 124$, and $64 \times$ $119 \mu \mathrm{m}$, respectively. Cadal ramus $104 \times 40 \mu \mathrm{m}$ (ratio 2.60 : $1)$.

Rostrum, antennules and antenna not different from those of female. Labrum not observed. Mandible, paragnath and maxillule as in female. Maxilla (Fig. 9E) different from that of female; its distal segment transformed to strong claw bearing 3 subdistal setae (one of them small and hardly visible). Maxilliped (Fig. 9F) consisting of 3 segments and terminal claw. First segment with 1 large pinnate seta. Second segment greatly expanded proximally with 3 longitudinal rows of spinules and 2 inner setae (distal one of latters unilaterally pinnate, proximal one very small and hardly visible). Small third segment unarmed. Terminal claw weakly curved and accom- panied by 2 small proximal setae.

Legs 1-4 not different from those of female in shape and armature. Leg 5 2-segmented, but proximal segment fused to fifth pedigerous somite. Distal free segment (Fig. 9G) different in shape from that of female, not curved, $104 \times 58$ $\mu \mathrm{m}$ (ratio 1.79:1), with pointed process near base of first and second outer spines. Leg 6 represented by 1 spine on genital flap (Fig. 9D).

Etymology. The specific name membranatus refers to the presence of the membranous fringe on the margins of the cephalothorax

Remarks. Hemicyclops membranatus n. sp. may be typified by two outstanding features: 1) the presence of the membranous fringe along the margins of cephalothorax and 2) a claw on the third segment of antenna. The first character has not been reported in the genus Hemicyclops and is, therefore, a unique feature of $H$. membranatus. In the presence of claw on the third antennal segment, H. membranatus is comparable to $H$. cylindraceus Pelseneer, 1929 associated with a bivalve in West Europe and H. livingstoni (T. Scott, 1894) known from a plankton sample in West Africa.

In the redescription of $H$. cylindraceus, Stock (1954) recorded this species to bear a cylindrical body, two spines and two setae (rather than one claw and three setae, as in $H$. membranatus) on the third segment of antenna, a bifurcate distal process on the distal segment of maxilla, and four setae (rather than three spines and one seta, as in H. membranatus) on the distal segment of leg 5. These features are not applicable to $H$. membranatus. It is remarkable that although $H$. cylindraceus is clearly different from $H$. membranatus, both of these two species exhibit that the terminal segment of female maxilliped bears an enlarged spine and a reduced spine in addition to setae.

In the original description of $H$. livingstoni, Scott (1894) described and illustrated that it possesses "two stout curved spines" on the third segment of the antenna and four setae on the distal segment of leg 5. In these respects, $H$. livingstoni is related to $H$. cylindraceus but differs from $H$. membranatus. In fact, the antenna and leg 5 of $H$. livingstoni and H. cylindraceus are of unusual for the genus Hemicyclops. Both species are probable to be turned out to belong to a separate genus in the future.

\section{ACKNOWLEDGEMENTS}

This study was carried out as a part of the project "The Discovery of Korean Indigenous Species" supported by the National Institute of Biological Resources (NIBR), Korea. 


\section{REFERENCES}

Ho, J.-S. and I.-H. Kim, 1990. Hemicyclops ctenidis, a new poecilostomatoid copepod (Clausidiidae) associated with a polychaete in Korea. Korean J. Zool., 33: 231-237.

Ho, J.-S. and I.-H. Kim, 1991. Two new species of the genus Hemicyclops (Copepoda, Poecilostomatoida, Clausidiidae) from crab burrows in the Yellow Sea. Korean J. Zool., 34: 289-299.

Humes, A.G. and R.U. Gooding, 1964. A method for studying the external anatomy of copepods. Custaceana, 6: 238-240.

Karanovic, T., 2008. Marine interstitial Poecilostomatoida and Cyclopoida (Copepoda) of Australia. Crustaceana Monograph, 9: 1-331.

Kihara, T.C. and C.E.F. da Rocha, 1993. Two new species Hemicyclops (Copepoda: Poecilostomatoida: Clausidiidae) associated with mud shrimps of the genus Callichirus from Brazil. Bijdr. Dierk., 63(4): 243-254.

Kim, I.-H., 2000. Poecilostomatoid copepods from an intertidal mud flat in the Yellow Sea. J. Nat. Hist., 34(3): 367-432.

Kim, I.-H., 2009. Poecilostome copepods (Crustacea: Cyclopoida) associated with marine invertebrates from tropical waters. Korean J. Syst. Zool., Special Issue 7: 1-90.

Nicholls, A.G., 1944. Littoral Copepoda from South Australia (II) Calanoida, Cyclopoida, Notodelphyoida, Monstrilloida and Caligoida. Rec. S. Aust. Mus., 8(1): 1-62.

Ohtsuka, S., K. Tomikawa and X. Shang, 2010. A new species of Hemicyclops (Crustacea: Copepoda: Cyclopoida) found in plankton at the mouth of the Jiulong River, southern China. Species Diversity, 15(1): 41-50.

Scott, T., 1894. Report on Entomostraca from the Gulf of Guinea, collected by John Rattrey, B. Sc. Trans. Linn. Soc. Lond., Zool., 2(6): 1-161, pls. 1-15.

Scott, T. and A. Scott, 1892. On new and rare Crustacea from the east coast of Scotland. Ann. Scot. Nat. Hist., 1892(3): 149-156, pls. $6,7$.

Stock, J.H., 1954. Redescription de Tococheres cylindraceus Pelseneer, 1929, copépode commensal de Loripes lacteus. Beaufortia, 4(38): 73-90.

Stock, J.H., 1959. Copepoda associated with Neapolitan invertebrates. Pubbl. Staz. Zool. Napoli, 31(1): 59-75.

Thompson, I.C. and A. Scott, 1903. Report on the Copepoda collected by Professor Herdman, at Ceylon, in 1902. In: W. A. Herdman, Report to the Government of Ceylon on the Pearl Oyster Fisheries of the Gulf of Manaar, 1, suppl. 7: 227-307, pls. 1-20.

Received October 17, 2010 Accepted November 12, 2010 